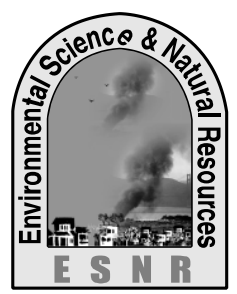

\title{
Investigation of the Household Waste Generation and Wastewater Management Techniques in Bogra Municipal Area
}

\author{
M. S. Rahman ${ }^{1}$, A. K. M. M. Hasan ${ }^{2}$, M. Rahman ${ }^{3}$, N. T. Meghla ${ }^{4}$ and M. A. Islam ${ }^{1 *}$ \\ ${ }^{1}$ Department of Environmental Science, \\ Bangladesh Agricultural University, Mymensingh-2202 \\ ${ }^{2}$ Department of Fish Biology and Genetics, \\ Sylhet Agricultural University, Sylhet-3100 \\ ${ }^{3}$ Department of Geography and Environment, \\ University of Dhaka, Dhaka-1000 \\ ${ }^{4}$ Department of Environmental Science and Resource Management, \\ Mawlana Bhashani Science and Technology University, Tangail. \\ *Corresponding author: islamaminulak@gmail.com
}

\begin{abstract}
The study was conducted to investigate the household waste generation and wastewater management phenomena in the Bogra municipal area during the period from October 2014 to April 2015, One hundred respondents from 7 wards of Bogra municipality were interviewed to carry out the study. The study investigated that the awareness level of the respondents increases with higher education and they indicated the crude disposal of municipal solid waste as the source of health hazards and environmental pollution. Result of the study showed that $\mathrm{pH}$ was slightly acidic, the concentration of sodium (Na) and sulfur (S) exceeded than desired level where nitrogen $(\mathrm{N})$ and phosphorus $(\mathrm{P})$ were within the effluent standard limit set by DoE. As the quality of wastewater was not satisfactory, it is necessary to explore possible treatment requirements before discharge to the natural stream. Bogra municipal authority should improve municipal waste collection and disposal system to maintain sound environment of the area. Various NGOs and local clubs should also take steps to keep the environment clean.
\end{abstract}

Key words: Awareness level, Household waste, Wastewater

\section{Introduction}

Waste and are unwanted or unusable materials. Waste is any substance which is discarded after primary use, or it is worthless, defective and of no use. The term is often subjective (because what is waste to one need not necessarily be waste to another) and sometimes objectively inaccurate (for example, to send scrap metals to a landfill is to inaccurately classify them as waste, because they are recyclable). Examples include municipal solid waste (household trash/refuse), hazardous waste, wastewater (such as sewage, which contains bodily wastes (feces and urine) and surface runoff), radioactive waste, and others. Waste is an unavoidable by-product of human activities. Economic development, urbanization and improving living standards in cities, have led to an increase in the quantity and complexity of generated waste (Zahur, 2007). Unfortunately, disposal of wastes in developing countries like Bangladesh is commonly done by dumping into low land or into water bodies or throwing for land filling. All these methods have varying degrees of negative environmental impacts with adverse environmental and health risks if wastes are not properly disposed or stored (Billah and Iqubal, 2011). Liquid waste is the wastewater that is collected from homes, businesses, industries and institutions through vast networks of sewer pipes that is increasingly recognized as a resource from which nutrients, energy, and water may be recovered and reused. Resource recovery can help to offset a portion of the costs associated with liquid waste management (Chair, 2010). Municipal wastewater, which is $99 \%$ liquid, consists of suspended and dissolved solids, both organic and inorganic, and includes large numbers of microorganisms (Alberta Environment, 2000). However, municipal solid waste management needs to be widely practiced in Bangladesh. Recently, some NGOs, CBOs and private organization are working with city authorities (Alamgir et al. 2007), which revealed that solid waste disposal poses a greater problem because it leads to land pollution if openly dumped, water pollution if dumped in low lands and air pollution if burnt (Hai and Ali, 2005). Residential waste collection from municipalities is strongly inter-correlated to public health and environment (Williams and Kelly, 2003). Waste management is the great concern in Bogra Municipal Area. Over many years, Bogra Municipal Area have been suffering from low standard of service in respect of street cleaning, collection, disposal of domestic and trade wastes which poses potential threats to the community's health and environment. Wastes are thrown in the open dustbin and road side that produce bad odor and spread diseases. The waste collectors also collect wastes irregularly. Several research works have done to assess the scenario of domestic solid waste management and disposal system in Bogra Municipal Area. But the situation remains unchanged. To ensure a good quality of life in a city, the environmental conditions within which a city dweller is living is of utmost importance (Murtaza, 2001). Keeping these views in mind the present study was designed in Bogra Municipal Area.

\section{Materials and Methods}

\section{Study area}

The study site was Ward no 04 and 06 under Bogra Municipal Area. The Latitude and Longitude of Bogra is 24.85 and 89.3667 respectively. The Bogra Municipal Area Covers a Population of 576,000 people. It consists of 21 wards (BBS, 2001). 


\section{Study duration}

The study was conducted from October 2014 to April 2015 in the Bogra municipal area.

\section{Research design and data collection}

This study mainly focused on the present status of solid waste management practice in Bogra Municipal area. Data collection included solid waste collection, transportation, and storage and disposal system in selected area. These studies identify the lacking of waste management and the authority future management plan. Both qualitative and quantities data were collected through direct field observation of the study area, focus group discussion with the stakeholders, secondary information were also collected for proper documentation, like research articles, books, periodicals. Both primary and secondary sources were used to collect data as fulfillment of the study.

\section{Sample analysis}

The water quality parameter such as $\mathrm{pH}$ was determined by the digital $\mathrm{pH}$ meter (Model: $\mathrm{pH}$ Scan WP 1, 2 and made in Malaysia. The nitrogen $(\mathrm{N})$ content of water samples was determined by Semi-micro Kjeldahl method, available phosphorus (P) by Olsen method/ sodium bicarbonate method, exchangeable potassium $(\mathrm{K})$ by ammonium acetate extraction method where ammonium acetate $(1 \mathrm{~N})$ was used as a reagent. The available sulfur $(S)$ in water was measured by calcium chloride extraction method and cation exchange capacity method was used to determine the available sodium
(Na) in water where flame photometer was used for identification. The available carbonate $\left(\mathrm{CO}_{3}\right.$ ) and bicarbonate $\left(\mathrm{HCO}_{3}{ }^{-}\right)$in water were determined by titration method where samples were filtered with Whatman No. 41 (Sattar and Rahman, 1987).

\section{Statistical analysis}

The collected data were analyzed by using SPSS (Statistical package for social science), version 11.5 and MS Excel 2010.

\section{Results and Discussions}

The study investigated the education level of the respondents, where it was observed that the highest percentage $(40 \%)$ of the respondent's educational level is graduation and the lowest percentage $(7 \%)$ of the respondent's educational level is up to primary. Higher education influences the awareness level of waste collection services that provided by municipality (Table 1). Most of the residents are aware about the solid waste management system but there is lacking of practice in their daily life. Islam et al. (2010) also stated that people were not aware of source separation of their household wastes and disposed wastes on the road side or drain side because of inadequate dustbins along with other problems in disposing of wastes. The Bogra Municipality does not have any solid waste processing and treatment system. Solid wastes are dumped on open areas through crude dumping without any treatment and sanitary land-filling (Islam et al. 2010) that degrade the environmental quality.

Table 1. Education level of respondents in respect of waste management system in the municipal area

\begin{tabular}{cccc}
\hline Categories of education & Frequency & Percentage $(\%)$ & \% of awareness \\
\hline Illiterate & 13 & 13 & 32.32 \\
Sign only & 16 & 16 & 28.57 \\
Primary & 7 & 7 & 42.54 \\
SSC & 9 & 9 & 87.83 \\
HSC & 15 & 15 & 100 \\
Graduation and more & 40 & 40 & 100 \\
\hline
\end{tabular}

The respondents gave their opinion regarding 10 enlisted common diseases faced due to waste generation and ineffective waste management practices, where it is reported that poor solid waste disposal is responsible for diarrheal diseases as stated by majority (24\%) of the respondents (Table 2). Animal diseases cited by the minor respondents (4\%). The study also cited that any respondents did not face the kidney problem and soil pollution oriented hazards during the study period (Table 2).

Table 2. Respondent's perceptions about waste generation related problems due to inadequate solid waste disposal

\begin{tabular}{|c|c|c|}
\hline Problems & Frequency & Percentage (\%) \\
\hline Air pollution & 6 & 6 \\
\hline Diarrhea & 24 & 9 \\
\hline Skin diseases & 9 & 0 \\
\hline Kidney & 0 & 11 \\
\hline Cholera & 11 & 15 \\
\hline Environmental pollution & 15 & 19 \\
\hline Mosquitoes & 19 & 0 \\
\hline Soil pollution & 0 & 4 \\
\hline Animal diseases & 4 & 14 \\
\hline Bad smell & 14 & \\
\hline
\end{tabular}


Waste creates severe environmental pollution which affects human health and entire component of ecology. Uncontrolled wastes, mixed with human and animal excreta scattered or spread indiscriminately on the road side, in the streets and in drain contributing to flooding, breeding of insect and rodent vectors and spread diseases (UNEP, 1996). It was observed that 20,
$20,17,8,7,6$ and $4 \%$ respondents mentioned the eight different hazardous solid wastes viz. kitchen waste, sludge from drain, leftover from fish and meat, noncompostable waste, poultry intestine, plastic and polythene and broken glass waste, respectively (Table $3)$.

Table 3. Respondent's perceptions about hazards of solid wastes in the municipal area

\begin{tabular}{|c|c|c|}
\hline Types of wastes & Frequency & Frequency \\
\hline Kitchen waste & 20 & 20 \\
\hline Sludge from the drain & 20 & 6 \\
\hline Plastic and polythene & 6 & 17 \\
\hline Left over from fish and meat & 17 & 4 \\
\hline Broken glass & 4 & 18 \\
\hline Poultry intestines & 7 & 8 \\
\hline All kinds of waste & 18 & 20 \\
\hline Non compostable waste & 8 & 100 \\
\hline Kitchen waste & 20 & 100 \\
\hline Total & 10 the \\
\hline
\end{tabular}

Untreated waste disposal into surface water pollutes the water which affects the health of poor people mostly, who cannot afford to choose between contaminated and non-contaminated sources. In raw water sources $\mathrm{pH}$ lies within the range of 6.5 to 8.5 (Ahmed and Reazuddin, 2000). The $\mathrm{pH}$ measured in the studied waste water ranged from 4.10 to 7.26 . On the other hand, the standard $\mathrm{pH}$ concentration of wastewater should be 6.0 to 9.0 before discharging into natural stream (DoE, 1997). Hence, the studied water samples were acidic in nature in most of the cases.

Table 4. Analyzed chemical properties of household wastewater in Bogra Municipality

\begin{tabular}{ccccccc}
\hline Sample no & $\begin{array}{c}\text { Nitrogen } \\
(\mathrm{ppm})\end{array}$ & $\begin{array}{c}\text { Potassium } \\
(\mathrm{ppm})\end{array}$ & Phosphorus (ppm) & $\begin{array}{c}\text { Sulfur } \\
(\mathrm{ppm})\end{array}$ & $\begin{array}{c}\text { Carbonate } \\
(\mathrm{ppm})\end{array}$ & $\begin{array}{c}\text { Bicarbonate } \\
(\mathrm{ppm})\end{array}$ \\
\hline 1 & 11.2 & 15.30 & 1.35 & 17.08 & 14 & 395.1 \\
2 & 13.4 & 16.55 & 1.52 & 20.01 & 7 & 366 \\
3 & 16.5 & 18.57 & 3.59 & 28.30 & 0 & 341.6 \\
4 & 13.6 & 54.49 & 1.78 & 18.89 & 0 & 286.7 \\
5 & 15.5 & 80.8 & 2.33 & 22.42 & 0 & 433.1 \\
6 & 20.4 & 84.76 & 6.89 & 40.98 & 0 & 354.2 \\
7 & 23.5 & 100.98 & 7.11 & 30.98 & 0 & 356.5 \\
8 & 19.3 & 78.78 & 4.93 & 54.90 & 0 & 366.6 \\
9 & 19.6 & 82.63 & 3.61 & 29.49 & 11 & 384.4 \\
10 & 13.4 & 86.99 & 4.59 & 35.58 & 6 & 359.1 \\
11 & 20.4 & 54.10 & 2.19 & 20.65 & 13 & 354.2 \\
12 & 19.9 & 49.20 & 4.88 & 27.36 & 0 & 368.5 \\
\hline DoE Standard & 100 & Not known & 8 & 1 & Not known & Not known \\
$(1997)$ & & & & & & \\
\hline
\end{tabular}

The studied waste water samples also analyzed to detect the N, P. K, S, Na, $\mathrm{CO}_{3}{ }^{-}$and $\mathrm{HCO}_{3}^{-}$. About $10 \mathrm{mg} / \mathrm{l}$ as $\left(\mathrm{NO}_{3}{ }^{-}, \mathrm{N}\right)$ or greater may be regarded as a probable indication of contamination from fertilizers, municipal wastewaters, feedlots and septic systems (Nikanorov et al., 1993). Hence, the result of the present study showed that the total kjeldahl nitrogen $(\mathrm{N})$ content was within the standard limit (Table 4) in all samples of wastewater. Phosphorus content in the wastewater was ranged from 1.35 to $7.11 \mathrm{ppm}$ (Table 4) that also within the standard level of $8 \mathrm{ppm}$ (DoE, 1997). The typical range of total dissolved phosphorus in municipal wastewater is between 2 and $6 \mathrm{mg} / \mathrm{l}$ (Alberta Environment, 2000). Higher concentration of $\mathrm{K}$ was observed in the study area. Concentrations of $\mathrm{K}$ in natural waters are usually less than $10 \mathrm{mg} / \mathrm{l}$, whereas concentrations as high as 100 and $25,000 \mathrm{mg} / \mathrm{l} \mathrm{can}$ occur in hot spring and brines, respectively (Hem, 1989). Alberta Environment (2000) reported that the typical range for $\mathrm{K}$ in most municipal wastewaters is 5 to $40 \mathrm{mgl}^{-1}$. Excessive concentration of $\mathrm{K}$ in surface water decreases the growth of aquatic plants and fish 
species. The sulfur concentration was ranged from 17.08 to $54.90 \mathrm{ppm}$ in the study area (Table 4) as compared with DoE standard. The maximum and minimum concentration of $\mathrm{Na}$ in the collected samples was 296.07 and $89.08 \mathrm{ppm}$, respectively. The sample no. 6,7 and 8 exceeded the standard concentration of 200 ppm set by DoE (2003) where all the sample except sample no. 1 exceeded the standard level of EPA (1997) (100 ppm) which indicates that the water was not suitable for use. The high concentration of $\mathrm{Na}$ in wastewater decreased the quality of surface water specially pond water in the municipal area. The concentration of $\mathrm{Na}$ and $\mathrm{P}$ showed the vice-versa relationship i.e. the higher the $\mathrm{Na}$, the lower the $\mathrm{P}$ in wastewater.

Carbonate is uncommon in natural surface water because they rarely exceed $\mathrm{pH} 9$, whereas ground waters can be more alkaline and may have concentrations of carbonate up to $10 \mathrm{mg} / 1$ (Bartram, 1996). The maximum concentration of $\mathrm{CO}_{3}{ }^{-}$was 15.5 ppm in the study area where most of the areas showed zero or below $10 \mathrm{ppm}$ concentration (Table 4). Carbonate depends on $\mathrm{pH}$ range. Excessive concentration of $\mathrm{CO}_{3}{ }^{-}$degrades the water quality and increases pollution. The $\mathrm{HCO}_{3}{ }^{-}$concentration in surface water is usually $<500 \mathrm{mg} / \mathrm{I}$ and commonly $<25 \mathrm{mg} / \mathrm{l}$ (APHA, 1989).

\section{Conclusions}

From the findings of study, it was evident that the residents are generally aware about waste generation and its impact due to high literacy rate in the studied area. The household wastewater is directly disposed into the open places, nearby low lands and ponds, and thus deteriorating the environment and also create some common diseases in the study area. The study was a small step to assess the scenario because only 7 wards were considered out of 18 wards. Some physicochemical parameters such as EC, TDS, suspended solids, DO, BOD, chlorides etc. were not measured that was a major limitation of the study. So in near future a broad-scale research is needed covering majority checklist of the environment. However, to improve the environment of the municipal area, the authority should take initiatives to encourage people to separate degradable and non-degradable household waste, and finally dispose into the dustbin. The number of dustbin should be increased and set up in the appropriate locations, where adequate manpower and vehicles should be increased to accelerate door-to-door waste collection services and at the same time maintained controlled disposal at landfill sites. Besides Bogra municipal authority, various CBOs, NGOs, local clubs should be involved to improve the collection, recycle, reuse and treatment techniques for effective household waste management and keep the environment clean in the Bogra municipal area of Bangladesh.

\section{References}

Ahmed, A. U. and Reazuddin, M. 2000. Industrial Pollution of Water Systems in Bangladesh. In: Rahman, A. A. fluq, S. and G. R. Conway (ed.), Environmental System of Surface Water Systems of Bangladesh, University Press Limited, Dhaka, Bangladesh, 175-178 pp.

Alamgir, M.; Bidlingmaier, W.; Glawe, U.; Martens, J.; Sharif, L. A.; Visvanathan, C. and Stepniewski, W. 2007. Safe and Sustainable Management of Municipal Solid Waste in Khulna City of Bangladesh. In: Eleventh International Waste Management and Landfill Symposium, Italy.

Alberta Environment. 2000. Guidelines for Municipal Wastewater Irrigation, Edmonton, Alberta, 9-10 pp.

APHA (American Public Health Association). 1989. Standard Methods for the Examination of Water and Wastewater. 17th edition, American Public Health Association, Washington D.C. 1-268 pp.

Bangladesh Bureau of Statistics (BBS) 2001. and National Institute of Local Government, 2002.

Bartram, J. and Balance, R. 1996. (Ed.) Water Quality Monitoring: A Practical Guide to the Design of Freshwater Quality Studies and Monitoring Programme. Published on behalf of UNDP and WHO Chapman and Hall, London. 383 pp.

Billah. A. H. M. M. and Iqubal, K. F. 2011. Urban Solid Waste Management: Social Impacts and Implications. Group Export on Environment and Nature (GREEN), Dhaka, p. 9.

Chair, E. J. 2010. Integrated Liquid Waste and Resource Management. Environmental Protection Division, Columbia. p. 5.

Department of Environment (DoE). 2003. A compilation of environmental laws of Bangladesh. Ministry of Environment and Forest, Government of the People's Republic of Bangladesh.

Hai, E. I. and Ali, M. A. 2005. A Study on Solid Waste Management System of Dhaka City Corporation: Effect of Composting and Landfill Location. UAP J. Civil Environ. Engg., 1(1):18-26.

Hem, J. D. 1989. Study and Interpretation of the Chemical Characteristics of Natural Waters. Water Supply Paper, 3rd edition, U.S. Geological Survey, Washington D. C. p. 263.

Islam, M. S.; Roy, S.; Dutta, S.; Das, K. C. and F. Zahan. 2010. Assessment of Domestic Waste Disposal System in Tangail Municipal Area. J. Environ. Sci. \& Natur. Res., 3(1):163-168.

Murtaza, G. 2001. Environmental Problems in Khulna City, Bangladesh: a Spatio-Household Level Study, $1(2): 32-37$

Sattar, M. A. and Rahman, M. M. 1987. Techniques of soil anal. Pak Press. Bogra, Bangladesh, 87-124 pp.

United Nation Environment Programme (UNEP). 1996. International source Book on Environmental Sound Technologies for Municipal Solid waste Management.

Williams, I. D. and Kelly, J. 2003. Green waste collection and public's recycling behavior in the Brough of wyre, England. Resources, conservation and recycling, 38: 139-159

Zahur, M. 2007. Solid Waste Management of Dhaka City:Public Private Community Partnership. BRAC Univ. J., 15(2):93-97. 